\title{
Effectiveness of Teaching Methods for Toothbrushing in Preschool Children
}

\author{
Soraya Coelho LEAL ${ }^{1}$ \\ Ana Cristina Barreto BEZERRA ${ }^{2}$ \\ Orlando Ayrton de TOLEDO ${ }^{2}$ \\ ${ }^{1}$ Area of Morphology, Faculty of Medicine, UnB, Brasília, DF, Brazil \\ ${ }^{2}$ Department of Dentistry, Faculty of Health Sciences, UnB, Brasília, DF, Brazil
}

\begin{abstract}
Three different methods of instruction and motivation were used to assess the learning process and ability of preschool children in performing toothbrushing. Forty children from a private nursery of Brasília, DF, Brazil, were divided into 2 groups according to age (3-4 years old and 5-6 years old). The following methods of instruction and reinforcement were applied: I - audiovisual; II - child as a model; III - individual instruction. Professional prophylaxis was then performed and the children remained 48 hours without any kind of oral hygiene. Plaque disclosing and plaque index were carried out and recorded. The children subsequently brushed their teeth according to each method of instruction and a new plaque index was recorded. The data were analyzed statistically using the Student t-test and the comparison of two proportions. The results showed that the children of both groups reduced plaque index and that the individual instruction method was superior $(\mathrm{p}<0.05)$ to the others at all ages. Children older than 5 years of age were able to learn and accomplish toothbrushing better than younger children.
\end{abstract}

Key Words: children, toothbrushing, education, plaque index.

\section{INTRODUCTION}

It is known that the three basic circles from PaulKeys (1) display the basic etiological factors of dental caries. One of them is undoubtedly the microorganism, which accumulates and forms biofilm, known as dental plaque. Although there is no scientific based evidence correlating biofilm and dental caries, it is accepted that plaque removal is a very advisable procedure for oral health maintenance.

There is evidence that the mechanical control of plaque prevents gingivitis and reduces plaque $(2,5)$. Thus, toothbrushing continues to be the most used and effective method for cleaning most tooth surfaces (6).

Toothbrushing, as all habits of hygiene, is acquired during the socialization process of the child (7). When this habit is taught in early childhood, it is naturally ingrained in the daily routine of the child, with only positive reinforcement needed later (8-9). Toothbrushing can be compared with other health-related habits that will persist throughout life without great changes (10), e.g. excessive use of sugar.

Nevertheless, it is generally known that toothbrushing by children under ten years of age is inefficient (11). This difficulty can be explained by the lack of motivation and poor manual dexterity normal to this age (12). Effective plaque removal instruction can be taught when the child is an active part of oral hygiene education $(8,13)$. Instructions should be given according to the child's degree of readiness for toothbrushing and should include systematic training and reinforcement. Although manual dexterity and ability are necessary, intensive individual training is essential $(13,14)$. Children should be educated in oral self-care according to their status of psychological development (15).

Oral hygiene instructions through educational lectures result in highly significant improvements in oral health (16). However, there is evidence that the development of grammatical understanding in very young children continues for several years. This could explain the difficulty found in the training and practice of oral hygiene techniques in preschool children using 
only verbal instructions (17). The use of audiovisual methods is also suggested for these children (18).

Thus, this study assessed the effectiveness of 3 teaching methods for toothbrusing in preschool children: audiovisual, child as a model and individual instruction.

\section{MATERIAL AND METHODS}

The present study was developed in a private nursery school in Brasília, DF, Brazil by only one dentist. After the parents or legal guardian of the child signed an informed consent, forty children were selected as follows: age between 3-6 years, completed primary dentition, dmfs equal to zero, and only slight to mild gingivitis. The children were divided into 2 groups according to age: group 1 (G1): 20 subjects - 10 children of 3 years of age and 10 children of 4 years of age; group 2(G2): 20 subjects -10 children of 5 years of age and 10 children of 6 years of age.

Three methods of oral hygiene instruction and reinforcement were applied separately for G1 and G2. Method I - audiovisual: models and slide projection with subjects and motivation appropriate for each age group. Method II - child as a model: the dentist demonstrated toothbrushing technique using a child as a model. Method III - individual instruction: each child received individual instruction.

Two toothbrushes and toothpaste of the same brand were given to all children that participated in this study. One of the toothbrushes remained with the dentist and the other one with the child. The toothbrushing technique applied for all teeth and surfaces included only back-and-forth movements. Immediately after the

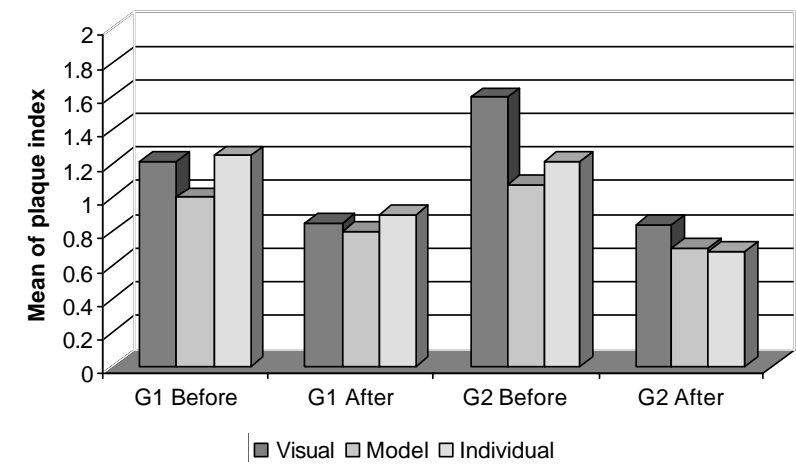

Figure 1. Mean of plaque index for G1 and G2 before and after the application of the three methods of oral hygiene and reinforcement. application of the Methods I, II, and III, the following procedures were performed: a) plaque disclosing and professional prophylaxis using a toothbrush and toothpaste in order to remove all plaque; b) the person responsible for the child was asked to not brush the child's teeth for $48 \mathrm{~h}$ for plaque accumulation; c) after $48 \mathrm{~h}$, each child brushed his or her teeth according to the instructions received before. Plaque disclosing was carried out before and after brushing for plaque index comparison. Scores were 0 for no plaque, 1 for thin plaque and 2 for thick plaque.

The data were statistically analyzed utilizing the Student t-test and the comparison of two proportions.

\section{RESULTS}

The total plaque index decreased in both groups after the application of the three methods of instruction and reinforcement. However, G2 had greater plaque reduction than $\mathrm{G} 1$ for all methods $(\mathrm{p}<0.05)$ (Figure 1).

Analyzing the instruction and reinforcement methods separately, when Method I was applied there was no statistical difference between $\mathrm{G} 1$ and $\mathrm{G} 2$ plaque index ( $>0.05)$ (Figure 2). After Method II was applied, G2 showed a significantly greater $(\mathrm{p}<0.05)$ percentage of zero plaque $(40.4 \%)$ compared to G1 $(31.7 \%)$ (Figure 3). Individual instruction (Method III) showed the greatest percentage of plaque index scores equal to zero for G2 $(45.8 \%)$ (Figure 4). On the other hand, the children of G1 maintained similar values of plaque index reduction to score zero for all three methods.

We conclude that the individual method showed the greatest difference between $\mathrm{G} 1$ and G2, followed by the audiovisual and the child as a model (Figure 1). All

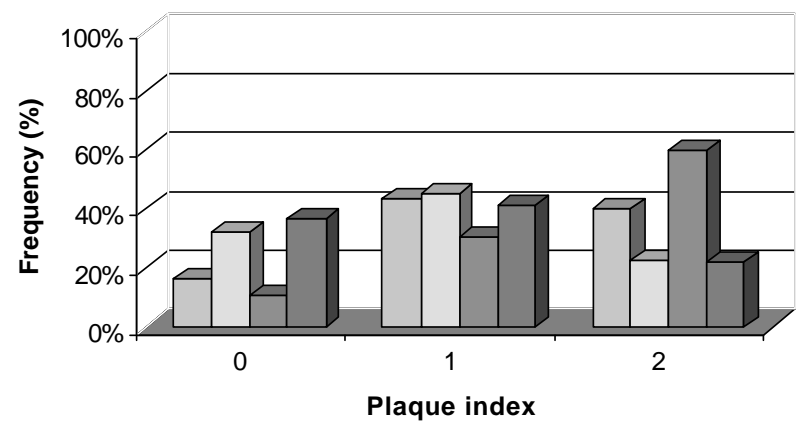

$\square$ G1 Before $\square$ G1 After $\square$ G2 Before $\square$ G2 After

Figure 2. Frequency of plaque index for G1 and G2 before and after the application of the audiovisual method (I). 
methods reduced the plaque index; however, the G2 (56 years old) children had better performance than G1 (3-4 years old) children.

\section{DISCUSSION}

The results showed a significant relation between the methods of oral hygiene instruction and reinforcement and the plaque index. These findings confirm earlier studies $(5,8)$ that suggest that instruction and supervision are important to establishing effective toothbrushing habits in children.

Williford et al. (16) reported that educational lectures result in highly significant improvements in oral health when applied in adolescents. However, this method is believed to be efficient only in children over five years of age. According to Simmons et al. (17), most children between 2 and 4 years of age are not able to understand the use of prepositions such as "on top of", "inside", "behind", etc. Thus, the difficulty found in teaching toothbrushing skills to these children using just words. Therefore, other methods, such as audiovisual should be indicated for preschool children (18).

The data obtained in this study showed that, after the application of the three methods of oral hygiene instruction and reinforcement, the children of both groups reduced plaque scores. However, the children of G2 (between 5 and 6 years) reached significantly more plaque scores equal to zero than the children of G1 (3 and 4 years of age). Unkel et al. (11) suggest that chronological age is a reasonable predictor of toothbrushing ability and that manual toothbrushing skills are acquired after approximately four to five years. Ogasawara et al. (14) affirm that it is possible to give

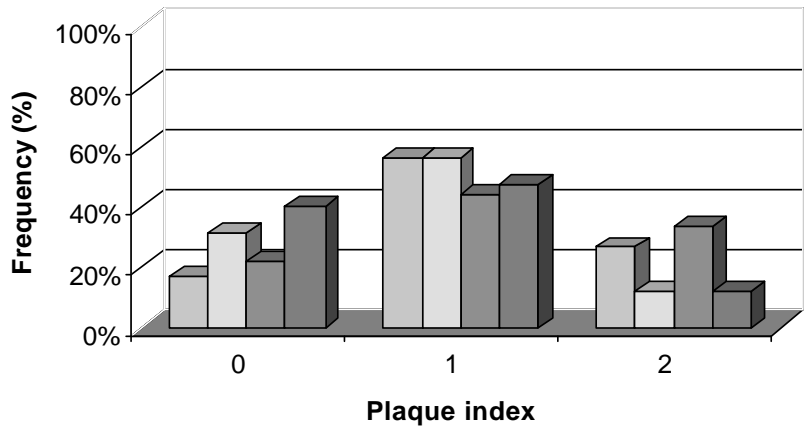

$\square$ G1 Before $\square$ G1 After $\square$ G2 Before $\square$ G2 After

Figure 3. Frequency of plaque index for G1 and G2 before and after the application of the child as a model method (II). effective guidance in toothbrushing to preschool children as long as the instructions are adapted to their age.

In the present study, the performance of preschool children in brushing their teeth was improved by motivation obtained when the three methods of oral hygiene were applied. Daly et al. (3) and Candelária et al. (13) reported that motivation, as demonstrated in this study, is one of the most important factors in ensuring optimal plaque control. Stutcliffe et al. (9) concluded that oral hygiene instruction programs have potential value as a means of introducing young children to future dental procedures in as pleasant a way as possible.

We conclude that it is necessary to find which method of oral hygiene instruction is more adequate for each child considering age. The results showed that the most effective method of oral hygiene instruction and reinforcement was individual instruction independent of the age of the child. This information is useful because this method is both inexpensive and easily taught.

\section{RESUMO}

Leal SC, Bezerra ACB, de Toledo OA. Avaliação da eficácia do ensinamento de métodos de escovação dentária em crianças préescolares. Braz Dent J 2002;13(2):133-136.

Com o objetivo de avaliar a capacidade de aprendizagem de crianças pré-escolares quanto às técnicas de escovação, foram utilizados três diferentes métodos de instrução e reforço, em uma creche de Brasília, DF. Quarenta crianças foram divididas por faixa etária em dois grupos de 3 e 4 anos de idade e 5 e 6 anos de idade, respectivamente. Foram aplicados os seguintes métodos de instrução e reforço: I - audiovisual, II - criança como modelo, III - instrução individual. Para a avaliação da eficácia dos

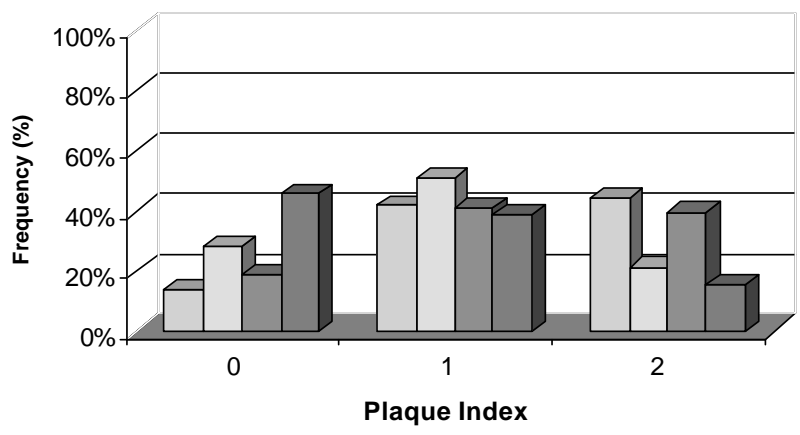

$\square$ G1 Before $\square$ G1 After $\square$ G2 Before $\square$ G2 After

Figure 4. Frequency of plaque index for G1 and G2 before and after the application of the individual instruction method (III). 
métodos, após a aplicação de cada um deles foi realizada profilaxia profissional e aguardou-se 48 horas sem que qualquer procedimento de higienização fosse efetuado. Foram realizados evidenciação de placa e o registro do índice de placa. As crianças fizeram a escovação de acordo com o que aprenderam através do método de instrução aplicado anteriormente e feito novo registro do índice de placa. Os dados foram analisados estatisticamente e mostraram que após a aplicação de todos os métodos houve redução do índice de placa para os dois grupos. Quando os métodos foram comparados entre si, o método de instrução individual foi o que apresentou melhores resultados. Outra conclusão foi de que as crianças de 5 e 6 anos apresentaram maior capacidade de desempenho e aprendizagem que as crianças de 3 e 4 anos de idade.

Unitermos: crianças, escovação, educação, índice de placa.

\section{REFERENCES}

1. Keys $\mathrm{PH}$, The infectious and transmissible nature of experimental caries. Arch Oral Biol 1960;1:304-320.

2. Ashley FP, Sainsbury RH. The effect of a school-based plaque control program on caries and gingivitis. Brit Dent J 1981;150:4145.

3. Daly CG, Chapple CC, Cameron AC. Effect of toothbrush wear on plaque control. J Clin Periodontol 1996;23:45-49.

4. Horowitz AM, Suomi JD, Peterson JK, Lyam BA. Effect of supervised daily plaque removal by children: Results after third and final year. IADR 1977;(Special Issue): 170.

5. Okada M, Kuwahara S, Kaihara Y, Ishidori H, Kawamura M, Miura K, Negasaka N. Relationship between gingival health and dental caries in children aged 7-12 years. J Oral Sci 2000;42:151155.

6. O`Leary T. Emphasis: current approaches to prevention control. J
Am Dent Assoc 1984;109:690-702.

7. García-Godoy F. La salud bucal como parte del processo de socializacion. Acta Odontol Pediat 1986;7:11-13.

8. Tsamtsouris A, White GE, Clark ER. The effect of instruction and supervised toothbrushing on the reduction of dental plaque in kindergarten children. J Dent Children 1979;36:204-209.

9. Stutcliffe P, Wishart WA, Naomi C. Supervised toothbrushing in a nursery school. Brit Dent J 1977;147:192-194.

10. Panuio P, Rautava P, Sillanpää M, Kaleva O. Dental health habits of 3-year-old Finnish children. Dent Oral Epidemiol 1993;21:47.

11. Unkel JH, Fenton SJ, Hobbs G, Frere CL. Toothbrushing ability is related to age in children. J Dent Children 1995;5:346-348.

12. Grossman E, Proskin H. A comparison of the efficacy and safety of an electric and a manual children's toothbrush. J Am Dent Assoc 1997; 128:469-474.

13. Candelária LFA, Teramoto L, Lopes AMS, Ortiz G, Moraes AT. Estudo sobre motivação e reforço de motivação em escovação dentária, em escolares de 7 a 10 anos. Rev Odont UNESP 1989;18:217-223.

14. Ogasawara $\mathrm{T}$, Watanabe $\mathrm{T}$, Kasahara $\mathrm{H}$. Readiness for toothbrushing of young children. J Dent Children 1992;5:353359.

15. Zimmer S, Bizhang M, Seemann R, Barthel CR. Effectiveness of preventive programs on oral hygiene of adults and school children. Gesundheitswesen 2001;63:98-101.

16. Williford JW, Muhler JC, Stookey GK. Study demonstrating improved oral health through education. J Am Dent Assoc 1967;75:896-902.

17. Simmons S, Smith R, Gelbier S. Effect of oral hygiene instruction on brushing skills in preschool children. Community Dent Oral Epidemiol 1983;11:193-198.

18. Bijjela MFTB: A importância da educação em saúde bucal nos programas preventivos para crianças. J Bras Odontoped Odontol do Bebê 1999;2:127-131. 